\title{
An Experiment in Bibliographic Instruction at Wabash College
}

\begin{abstract}
This article, condensed from a five-year report to the Council on Library Resources, presents content analysis and survey results of a program designed for bibliographic instruction at Wabash College. The project employed specially trained student assistants as the primary agents for information transfer. The program was beneficial to freshmen and sophomores aided by student assistants who were knowledgeable in many facets of academic life and who worked in closely structured courses that demanded regular library use.
\end{abstract}

\begin{abstract}
$\mathbf{I}_{\mathrm{s}}$ N 1970 the Council on Library Resources initiated its College Library Program designed to experiment with methods of strengthening the role of academic libraries in the educational process. Wabash College, Crawfordsville, Indiana, was one of the first four schools to be awarded a grant under the program. Initially, the project focused on freshman seminars led by a professor with the assistance of specially trained upperclassmen, which pursued topics chosen because of their interest to the participants. The upper division student assistants were, in turn, to respond to the information needs of students in the seminars.

The freshman seminars (later termed tutorials) were planned with the idea that students should move as rapidly as
\end{abstract}

John Mark Tucker is reference librarian, Wabash College, Crawfordsville, Indiana. The author is indebted to John H. Lawrie, associate professor of psychology at $\mathrm{Wa}$ bash College, for assistance in survey design and interpretation and to Barbara Easterling and Barbara Worosz for editorial assistance. The full report on which this article is based is available as an ERIC publication (ED 126940). possible into the intellectual life of the college. Faculty were encouraged to participate in that they could teach a topic of their own choosing, as broad, as narrow, or as unorthodox as their interests. Incoming students were offered the advantages of a small, informal classroom situation in which they could express their views and begin to feel "at home." Library-trained reference assistants were selected by several tutorial faculty to help in course preparation, class discussion, and bibliographic instruction.

During the period covered by the grant, twenty-five different faculty members employed a reference assistant, though not all did so simultaneously. This meant that in a given semester, six or seven teachers were involved in seminar settings, teaching with the aid of a bibliographic assistant. The assistants helped tutorial students select term paper and report topics and introduced them to LC subject headings and such resources as periodical indexes or guides to government documents.

The experiment was constantly changing, demanding redefinition and evaluation based on student and faculty input. There was a shift in target 
groups from students in freshman tutorials to students in beginning speech. This arrangement engaged two members of the speech faculty, four student assistants, and approximately 100 students each semester. There were regular adaptations in training sessions for student assistants based, of course, on their recommendations. For instance, early in the project, assistants were trained in workshops lasting two or three days; later, weekly seminars were substituted.

From the project's inception, participants sought to clarify the meaning of the grant's aims as well as its potential for improving the learning environment. It is characteristic of the Wabash community that students, faculty, and library personnel developed a variety of opinions regarding what the objectives and activities of the project actually ought to be. The wide range of faculty attitudes regarding a college library in its institutional context was noted in the report of a 1974 library evaluation team headed by Robert Wedgeworth. ${ }^{1}$ Some teachers conceive the library to be a group of colleagues actively engaged in teaching students the "ins and outs" of vital resources and research techniques; others view it simply as a book storage closet. In embracing such divergent viewpoints, Wabash is surely not unlike many other institutions of higher learning.

Although a few articles have already appeared, they deal primarily with the earlier years of the program, detailing its structure and articulating its philosophical bases. ${ }^{2}$ This paper reports on the Wabash College Library Project, telling, in practical terms, the story of what happened, presenting the results of recent evaluation measures, and assessing the project's impact during the 1970-76 period.

\section{Profile of Wabash College}

More than any other factor, the real character of a college defines what librarians can do for students, especially if what is attempted is to merit faculty support and if it is to have a meaningful interface with curricular objectives. Wabash has been an appropriate place to attempt a program of bibliographic instruction. As indicated in the North Central Association report in 1973, this undergraduate men's college strives for excellence, and one cannot be on the campus "for long without developing a deep respect for its history and present program." 3 The college takes pride in a curricular emphasis which firmly stamps the institution as one which offers a traditional liberal arts education.

The teaching and learning environment poses two notable difficulties. One is that while faculty rightly place a premium on the liberal arts, they are generally disinterested in "how to" course content with which they tend to categorize bibliographic instruction. A second issue is that, due to their academic backgrounds and experience with university libraries, faculty are often unable to see the pedagogical value of teaching undergraduates how to use the college library intelligently and independently. ${ }^{4}$ These two factors are endemic to many small colleges but are not so pervasive as to render ineffectual the faculty-library cooperation that has occurred at Wabash and elsewhere.

Those faculty who expressed interest in the project were readily able to observe the connection it could have with the curriculum. While members of the library staff saw the same connection, they also saw the project in the context of bibliographic instruction and orientation efforts being undertaken by colleges and universities nationwide. ${ }^{5}$

In addition to these views of the project, it can be said that the philosophy underlying the grant bespeaks more than bibliographic instruction or the curriculum connection. It also suggests 
greater visibility for the Lilly Library throughout the Wabash community, more observable activity within the building's walls, and a noticeable increase in the quality and diversity of demands made on the library by its patrons.

\section{Program Structure and STUDENT INVOLVEMENT}

Selected upper division students continue as focal points in the project. They began as assistants in seminars which have evolved into small tutorials featuring written and oral expression as a primary purpose, with subject matter being secondary. The kind of verbal give-and-take which faculty seek to foster in these classes grew to have only minimal connection with the depth of bibliographic instruction needed by the independent learner. Thus, as the program progressed, tutorial faculty tended to use student assistants less frequently.

The idea for another facet of the project, the "in-house program," originated with the faculty and was an effort to capitalize on the easy familiarity existing among fraternity brothers. (Approximately 70 percent of Wabash students are members of Greek letter fraternities.) We had hoped that student assistants would discuss research problems in informal situations. It could have been that participants' expectations were unduly high, but the in-house component was discontinued because assistants were uniformly dissatisfied with the frequency of these informal occasions. There was, however, the noticeable advantage that students who personally knew a reference assistant working in the library would feel freer to approach him for help than to approach a person they did not know, and for this reason we continue to recruit assistants from as many fraternities as possible. Most student assistants, in addition to tutorial or in-house responsi- bilities, opted for regular part-time duty at the reference desk. ${ }^{6}$

Since the success of the tutorial and in-house programs was not long-lived, we examined other areas, choosing students in a beginning speech course as the target group. Speech I is a course which "presents the fundamentals of speech composition and delivery" and in which "basic problems in speech are considered and analysis made of video tape recordings." 7 It has a high enrollment, necessitating four or five sections in a given semester and involving a majority of the students in either their freshman or sophomore year. Four mature students, selected by the faculty of the speech department, attend an eightweek seminar with the reference librarian in which they gain a familiarity with fundamental learning resources.

These students are teaching assistants. They work regularly with freshmen and sophomores in selecting topics, suggesting methods of research and types of sources, and in offering critiques of student speeches. They have helped students prepare better outlines, improve the quality of research, and develop greater clarity of thought. Thus, they have in many cases experienced productive personal and working relationships. Through dealing with problems such as a speaker's nervousness, poorly organized thinking, and student inertia, library assistants have also arrived at a new appreciation for the responsibilities of teaching.

The idea that students can play a semi-independent role in the education of both themselves and their peers is entirely consistent with the college's self-perception-that it lives by an ethic of rugged independence and individualism.

From its very beginning the college has steered an independent course. No fact of its history has been more important to the present character of the 
institution, for independence has always been an article of faith at Wabash. Because Wabash accepts no government funds, it enjoys a rare independence in determining its own affairs. Respect for independence, in individuals and institutions, is fundamental to the philosophy of Wabash today. ${ }^{8}$

Without attempting to assess the extent to which the college has been able to live up to this philosophy, it should be sufficient to say that it makes an honest attempt to do so. Therefore, the significant role of student assistants is emblematic of what is characteristically Wabash, that students can help to educate themselves.

\section{SURVEY REPORT}

The most ambitious of our evaluations was implemented in April and May 1975 as faculty concurred with librarians in survey design and interpretation. The purpose of the three-part survey was to gauge opinions about the library generally and the project specifically. The staff believed that general attitudes about the library directly related to the overall impact of the project and to possibilities for similar efforts in the future.

Questionnaires went to the twenty-five faculty who had used a student assistant either in freshman tutorials, Speech I, or other courses in which they thought an assistant could be profitably employed. Respondents must be described as a volunteer group because they freely chose a "library reference assistant." The rate of return in the faculty survey was 84 percent and, in general, respondents tended to be positive in their attitudes about the project. They viewed their work with student assistants as worthwhile though not overwhelmingly satisfactory. Sixteen of nineteen faculty members either "agreed" or "strongly agreed" that student assistants were "adequately trained in the use of library resources.”
A second questionnaire was mailed to 446 undergraduates who had access to a student assistant in a freshman tutorial, other class, or both. The return rate was 51 percent, including a number who had dropped out, transferred, or graduated. Students generally agreed that library assistants were familiar with resources, were willing to help, and should be made available in other courses. But they were not uniform in endorsing the notion that they would actually consult an assistant for help in using the library. While 49 percent responded that they had "sought help from the student assistant," at least 20 percent did not, an unusually high number of negative responses. Sixty-six percent of the respondents concluded that student assistants were knowledgeable about resources, 6 percent disagreed, and 28 percent were either neutral or did not respond to the question.

The third portion of the April-May survey was distributed to library reference assistants who had participated in tutorial, in-house, or Speech I facets of the project at any time during the grant period. The questionnaire did not try to differentiate between assistants for speech and for other courses but sought to determine the overall five-year impact. On a percentage basis there were more out-of-town residents in this group than the other two. Forty-six of seventyfive questionnaires were returned for a rate of 61 percent.

The library assistants felt that, in one way or another, training in the library project had valuable derivative effects. Assisting a faculty member was the most valued derivative of their experiences. Respondents were dissatisfied with the extent to which students sought their help at the reference desk and were slightly less dissatisfied with the frequency with which tutorial students approached them. These results should be viewed in the context of the regular student questionnaire in which 49 per- 
cent of the respondents reported having consulted a reference assistant.

\section{The Program's Impact on the College}

Are the college and the library different due to the CLR grant? One quite encouraging change is that the library was allowed to increase its staff which for many years was staffed by only one professional, although he was supported by a group that was capable but quite small. On one previous occasion, the years 1963-67, there was an additional professional position, but, by the spring of 1970, before the CLR program began, there was again only one professional. Today's larger full-time staff of three professionals and six assistants, due partially to the grant, was given a first-time opportunity-to arrange for a physically visible reference desk, staffed for an average of sixty hours per week, designed to be the focal point of patron service and in-depth as well as point-of-use instruction. This was something new to the college and has been received well enough that administrative financial support continues.

Further, we observe in the library staff more responsiveness to student needs, a commitment to help, a sense of pride in sensitive and effective reference service, and an interest in acquiring the knowledge necessary to strengthen such service. An atmosphere which has been prevalent among us is one of self-examination and, as indicated by Charlotte Millis in "Developing Awareness," one of personal, on-the-job accountability. ${ }^{9}$ There has been closer attention to workflow, space allocations, job descriptions, staff development, and faculty-staff relationships. Besides being more serviceoriented, technical processing staff members have conceptualized a broader and better integrated view of their positions.

Impact on faculty and students has been generally positive as demonstrated by questionnaire results. The wide range of faculty attitudes about the library's role in the college has already been mentioned; there were, however, twenty-five teachers who felt strongly enough about the program to employ an assistant one or more times. Several continue to examine newer methods of bibliographic instruction. These are people who were already strong library supporters and who helped us articulate our goals to their teaching colleagues.

Where students, and particularly student assistants, are concerned, the program was considered more than helpful. This observation has been supported by responses to the April-May survey and is also the conclusion of Richard Strawn, professor of French and director of the library project for the first two years. ${ }^{10}$ More importantly, we are now more careful listeners when students make suggestions about improving library service as a whole or aspects of the project in particular. Indeed, a number of our more valuable changes have been based on student evaluation and criticism.

We see evidence that more guided study and independent research are taking place. As Dr. Strawn has said, reference questions are increasingly particular. ${ }^{11}$ Further, interlibrary loan requests have increased significantly. Although records for 1970-72 are incomplete, we know that in 1973 we placed ninetyeight requests for books and photocopies combined. In 1974 that figure had jumped to 392 , and for 1975 it rose to 524. Believing independent study vital to the aims of the project and necessary for intelligent research, we purchased in 1974 an associate membership in the ACM Periodical Bank which is designed to provide undergraduates with access to periodical articles not in collections at their own institutions. ${ }^{12}$ The dramatic increase in requests indicates the accuracy of our perception that many student research needs were not being satisfied. Two factors which 
have kept loan requests from rising faster are (1) that student familiarity with interlibrary loan is in the developing stages, therefore, some have not allowed sufficient lead time for us to place a request, and (2) a number of students take weekend and evening trips to large universities to supplement Lilly's resources.

The program for students of speech works well for several reasons, one of which was suggested by Richard Strawn, who wrote that the problem with freshman seminars was that they unfolded rather than being "well-built ahead of time."13 Speech I can be described as well-built ahead of time. Dr. James Barnes, associate professor of history, is convinced that "the library assistant format works best when the topic for the course clearly lends itself to heavy library utilization." ${ }^{14}$ This happens in speech: students must use library resources on a regular basis.

Speech courses provide appropriate channels for general bibliographic instruction because they encompass a variety of subjects. Access to supporting evidence often demands familiarity with basic multi-subject resources: examples are Social Sciences Index, Statistical Abstract, New York Times Index, and Congressional Information Service Index.

Further, the assistant in speech actually serves as an upper division counselor, usually knowledgeable on a fundamental basis with a wide range of student interests. Naturally, the assistant's commitment is necessary to cement this relationship, but the key to meaningful interaction (that was not present in freshman tutorials) is that assistants were able to be of service in a broad range of areas. This observation has been borne out by students and assistants alike and is probably the result of personal relationships which may be seen as by-products of critique sessions. The fact that speech assistants could help in a number of areas made them more believable when they talked to students about library resources. Thus, for many students, bibliographic instruction has become a more practical and integral part of the teaching and learning environment.

\section{SumMary}

The college's proposal to the Council on Library Resources intoned the need to concentrate on making the library interweave with learning so that the one would be unthinkable without the other. When one recognizes the idealism and the rhetoric of such a goal, it is appropriate to conclude that in a limited but practical fashion, the potential of the library has been moved closer to the needs of the curriculum.

The movement began with freshman seminars which themselves were in such a state of ferment that they could not be depended upon to be the focal point of bibliographic instruction from year to year. Therefore, in trying to draw the classroom and the library closer together, we were encouraged to work with students in beginning speech courses, allowing us to introduce the use of multi-subject resources to a group of students who needed them on a regular basis. In so doing, we discovered the value of teaching about learning resources within the framework of what is traditional and what is acceptable in the intellectual life of the college.

\section{REFERENCES}

1. Robert Wedgeworth and James V. Jones, "Evaluation of the Lilly Library, Wabash College, February 27-March 1, 1974"
(Crawfordsville, Ind.: Wabash College, 1974), p.2-3.

2. Charlotte Hickman Millis, "The Wabash 


\section{Bibliographic Instruction / 209}

Project: A Centrifugal Program," Drexel Library Quarterly 7:365-74 (July, Oct. 1971); idem, "Involving Students in Library Orientation Projects: A Commitment to Help," in Sul H. Lee, ed., A Challenge for Academic Libraries: How to Motivate Students to Use the Library (Ann Arbor, Mich.: Pierian, 1973), p.63-98; idem, "Developing Awareness: A Behavioral Approach," in John Lubans, Jr., ed., Educating the Library User (New York: Bowker, 1974), p.350-63; Charlotte Millis and Donald E. Thompson, "Wabash College Library Project," Library Occurrent 23:31116, 332 (Feb. 1971); and Donald E. Thompson, "Utilizing a CLR/NEH Grant: A Report on Wabash College" (Paper presented at the College of Wooster Conference on Bibliographic Instruction, April 25, 1975).

3. North Central Association of Colleges and Secondary Schools, Commission on Institutions of Higher Education, "Report of a Visit to Wabash College, Crawfordsville, Indiana, March 18-21, 1973" (Crawfordsville, Ind.: Wabash College, 1973), p.1. Wabash is a small, private college with 80 faculty members and a student enrollment of about 850 .

4. Evan Ira Farber identified this problem as the "university-library syndrome," a phrase which he defined and an idea he articulated in "College Librarians and the University-Library Syndrome," in Evan Ira Farber and Ruth Walling, eds., The Academic Library: Essays in Honor of Guy R. Lyle (Metuchen, N.J.: Scarecrow, 1974), p.1223.

5. Though an active bibliographic instruction effort was new to Wabash, similar programs have been functioning at other institutions for a number of years. A fine historical survey of the literature has been written by Johnnie Givens, "The Use of Resources in the Learning Experience," Advances in Librarianship 4:149-74 (1974). One of the more recent and more comprehensive bibliographies, listing more than 350 references to books and articles, is by Maureen Krier, "Bibliographic Instruction: A Checklist of the Literature, 1931-1975," Reference Services Review 4:7-31 (Jan., March 1976).

6. William F. Heinlen reported on a program at California State University, Fresno, which, with regard to student assistants working at the reference desk, is quite similar to the Wabash program in "Using Student Assistants in Academic Reference," $R Q$ 15:323-25 (Summer 1976).

7. Wabash College: The Academic Bulletin 1976-77. (Crawfordsville, Ind.: Wabash College, 1976), p.103.

8. Wabash: The Freshman Catalog of Wabash College 1974-75 (Crawfordsville, Ind.: Wabash College, 1974), p.5. On a national scale, the student role as self-educator is, according to Thomas Kirk, more than just a passing fad. "There is little evidence that the concept of student-centered education, with the associated concepts-independent study, self-teaching, 'university without walls,' and continuing education-is about to go out of style. If the concept is here to stay, then the problem of information access, which is at the heart of student-centered education, remains a crucial concern to the academic community" (Thomas G. Kirk, "Problems in Library Instruction in Four-Year Colleges," in John Lubans, Jr., ed., Educating the Library User, p.85-86).

9. Millis, "Developing Awareness," p.353-54.

10. Dr. Strawn is one of several members of the Wabash community whose narrative evaluation was included in the final report on which this paper is based in Mark Tucker, "Five-Year Report and Evaluation on Project CLR No. 486 Presented to the Council on Library Resources" (Crawfordsville, Ind.: Lilly Library, Wabash College, 1975), p.42-43. Available as an ERIC publication (ED 126940).

11. Ibid.

12. For a study of the use of periodicals in college libraries and, particularly, for a statistical description of services provided by the ACM Periodical Bank, see Blair Stewart, "Periodicals and the Liberal Arts College Library," College \& Research Libraries 36: 371-78 (Sept. 1975).

13. Tucker, "Five-Year Report," p.42-43. Gordon Wiseman and Larry Barker emphasize the need to carefully structure courses which use student teaching assistants in "Peer Group Instruction: What Is It?" Speech Teacher 15:220-23 (Sept. 1966).

14. Ibid., p.41. 